\title{
Meningkatkan pemahaman pola hidup sehat melalui penyuluhan di gampong sungai pauh
}

Della Adelia ${ }^{1}$, Hildayani' ${ }^{2}$, Marimbun ${ }^{3}$

IAIN Langsa, Langsa, Indonesia

email: hildayani2204@gmail.com

\begin{abstract}
First received:
Revised:

Final Accepted:

01 January 2021

02 February 2021

04 April 2021

Abstrak

Tujuan kegiatan ini untuk meningkatkan pemahaman anak-anak Sungai Pauh terhadap pola hidup sehat, Serta menumbuhkan kesadaran tehadap masingmasing anak tentang pentingnya menjaga kesehatan terutama dalam masa pandemi. Metode yang digunakan untuk menjalankan program yang telah direncanakan adalah penyuluhan. Kegiatan ini dilakukan dengan dua kali penyuluhan dan 3 kali aksi lapangan seperti pembuatan apotek hidup, gotong royong, dan pembagian masker. Hasil pengabdian menunjukkan bertambahnya pemahaman anak-anak terhadap pentingnya menjaga pola hidup sehat, serta bertambahnya kesadaran terhadap anak untuk menjaga kesehatan pada masa pandemi. Hal ini juga dapat dilihat dari antusias anakanak dalam mengikuti kegiatan-kegiatan yang dilakukan untuk mengedukasi anak-anak tentang pola hidup sehat dan kepedulian terhadap kesehatan seperti mulai menggunakan masker.
\end{abstract}

Kata Kunci: : Pemahaman, Pola Hidup Sehat

\begin{abstract}
The purpose of this activity is to increase the understanding of the children of the Pauh River about a healthy lifestyle, as well as to raise awareness for each child about the importance of maintaining health, especially during a pandemic. The method used to run the program that has been planned is extension. This activity was carried out with two counseling sessions and 3 field actions such as building a living pharmacy, mutual cooperation, and distributing masks. The results of this community service show an increase in children's understanding of the importance of maintaining a healthy lifestyle, as well as increased awareness of children to maintain health during a pandemic. This can also be seen from the enthusiasm of the children in participating in activities carried out to educate children about healthy lifestyles and health care, such as starting to use masks
\end{abstract}

Keywords: Understanding, Healthy Lifestyle

\section{PENDAHULUAN}

Desa Sungai Pauh terletak pada wilayah pesisir barat Aceh Besar yang memiliki bentuk linier. Bangunan utama gampong adalah jalan utama pada sumbu Utara - Selatan. Dominasi penggunaan lahan berupa pemukiman penduduk yang berkembang di 
sepanjang ruas jalan utama dan di sepanjang jalan sekunder, area persawahan atau unsur pertanian dan perkebunan yang terletak setelah area pemukiman. Sebagian wilayah terdiri dari pemandangan rawa, dan sebagian lainnya adalah lahan dari area pertambakan dan juga hutan manggrove (hutan bakau). Gampong Sungai Pauh Kecamatan Langsa Barat dengan luas wilayah yang mencapai 631 hektare juga mengalami peningkatan penduduk yang membuat desa ini bertambah angka kelahiran penduduk setiap tahunnya. Desa Sungai Pauh sendiri terbegi dari empat bagian, yaitu Sungai Pauh Induk, Sugai Pauh Tanjung, Sugai Pauh Pusaka dan Sungai Pauh Firdaus. Karena gampong ini terbagi dari empat bagian, maka tiap-tiap gampong memiliki kepala gampong (geuchik) sendiri di masing - masing gampongnya. Menurut dari data pemerintahan yang penulis peroleh dari kantor geuchik. Kependudukan dari gampong ini sendiri terdiri dari 1.136 (seribu seratus tiga puluh enam) kepala keluarga dengan kisaran penduduk 5.590 (lima ribu lima ratus) jiwa.

Wabah virus corona adalah keluarga besar virus yang menyebabkan penyakit mulai dari gejala ringan sampai dengan berat. Ada setidaknya dua jenis coronavirus yang menyebabkan penyakit yang dapat menimbulkan gejala berat seperti Middle Easct Respiratory Syndrome (MERSCOV) dan Severe Acute Respiratiry Syndrome (SARSCOV). (Kesehatan, 2019) Viruscorona pertama kali berada di kota Wuhan China pada tahun 2019. Pada saat pertama kali virus corona mewabah Indonesia merupakan salah satu negara yang masih aman dari penularan virus ini. Sampai kemudian pada tahun 2020 tanggal 2 maret. Presiden RI pertama kali mengkonfirmasi bahwa virus telah masuk ke Indonesia. Sebelumnya Indonesia merupakan salah satu negara yang belum terinfeksi wabah virus corona. Namun, setelah dikonfirmasi masuknya wabah virus ke Indonesia, virus terus melunjak dan mengalami peningkatan. Pada pertengahan tahun 2020 kasus ini sempat menurun dan kembali meningkat pada akhir tahun seperti pada curva data covid yang menunjukkan perkembangan virus di indonesia. Memasuki tahun 2021 namun virus masih belum di konfirmasi bersih dan hilang dari negara, pemerintah masih terus menghimbau tentang keselamatan dan pematuhan protokol kesehatan. (Yunus \& Rezki, 2020) Penyebaran virus tidak terjadi merata pada seluruh daerah di Indonesia, masih banyak daerah yang termasuk memiliki angka yang kecil terpapar virus, seperti gampong Sungai Pauh.

Dengan penduduk yang terbilang cukup ramai serta pemukiman warga yang sedikit padat. Gampong ini termasuk salah satu gampong yang memilki angka penyebaran covid cukup kecil, hal inilah yang kemudian menjadikan beberapa penduduk desa terkadang acuh pada penularan virus corona. Terutama pada anak-anak di gampong ini yang masih 
suka bermain diluar rumah, berkumpul dengan teman yang terkadang mengabaikan protokol kesehatan. Sementara itu pemerintah sendiri sudah melakukan berbagai upaya dalam pencegahan covid, diantaranya pemerintah membatasi jam malam dan mencegah tempat-tempat ramai, memberikan edukasi tentang covid seperti menempelkan poster dan menyebar flayer dsb, serta membuat masyarakat terbiasa untuk selalau melakukan dan menajankan protokol kesehatan (Utomo, 2020). Hal ini pula kemudian yang membuat kami merasa ikut terpanggil untuk turut membantu pemerintah setempat dalam melakukan penghimbauan terhadap bahaya covid sehingga kami merencana program- program ini yang kami anggap dapat membantu pemerintah dalam pengedukasian masyarakat. (Karo, 2020). Karna penulis merasa, semakin banyak yang membantu untuk mengingatkan dan meningkatkan upaya dalam pencegahan covid, maka proses pengedukasian atau penyuluhan yang dilakukan pemerintah dalam menghindari dampak tertular covid dapat lebih merata prosesnya.

Pengedukasian anak-anak di gampong Sungai Pauh sangat penting dalam hal meningkatkan pemahaman mereka terhadap pola hidup sehat. Meskipun daerah ini merupakan daerah yang memiliki angka covid yang kecil. Namun pengedukasian ini dapat membantu mereka dalam menjaga kesehatan mereka sendiri saat berada diluar rumah. Serta menumbahkan kesadaran tehadap masing-masih anak tentang bagaimana pentingnya menjaga kesehatan terlebih dalam masa pandemi. (Safitri \& Harun, 2020) Oleh karena itu perlunya kegiatan seperti penyuluhan tentang bagaimana cara-cara pola hidup yang sehat dan tentu saja tidak hanya sebatas penyuluhan terhadap pola hidup yang sehat, namun juga tentang pengedukasian kepada lingkungan yang bersih untuk terjauh dari berbagai bakteri yang dapat menimbulkan penyakit. Hal ini agar dapat menambah pemahaman dan kesadaran anak-anak terhadap pentingnya hidup dengan cara yang sehat.

\section{METODE}

Metode yang digunakan dalam penelitian ini adalah penyuluhan melalui beberapa tahapan yang di anggap dapat membantu melancarkan kegiatan yang kami lakukan, diantaranya: Mendirikan apotek hidup sebagai himbauan yang menandakan bahwa masih ada tumbuhan yang memiliki khasiat penting untuk obat- obatan (Syarif et al., 2011). Proses pembuatan apotek hidup di anggap penting sebagai salah satu sarana penyuluhan. Pembudayaan apotek hidup yang di tanam di kantor geuchik dapat menjadi ide bagi masyarakat yang datang ke kantor geucik agar memanfaatkan tanaman herbal yang bisa mengobati berbagai macam penyakit di samping membudayakan dan 
menanam bunga.

Melakukan gotong royong dengan membersihkan tempat - tempat yang menjadi fasilitas umum dan banyak orang. Seiring dengan wabah yang menyebar, tentu saja tempat-tempat umum merupakan tempat yang paling wajib kita jaga kebersihannya (Messakh et al., 2019). Mengingat penyebaran virus yang tengah mewabah dapat berpindah dari tempat kepada manusia, hal ini harus menjadi perhatian karena masih banyaknya anak-anak yang bermain di lingkungan. Lingkungan yang bersih dan sehat adalah lingkungan yang bebas dari berbagai kotoran, termasuk diantaranya debu sampah dan bau. (Maulida et al., 2020). Karena proses penularan penyakit disebabkan oleh microbe, lingkungan yang bersih dan sehat berarti harus bebas dari virus, bakteri, dan berbagai sektor penyakit. Data dan profil gampong geuchik menunjukkan jumlah penduduk yang begitu padat, maka ditemui pemukiman penduduk yang cukup padat, sehingga diperlukan melakukan social distancing atau menjauhi diri dari keramaian. Social distancing merupakan salah satu cara untuk mengurangi meluasnya penyebaran virus corona. (Achyar, 2020) Permasalahan tentang lingkungan mempunyai pengaruh dengan manusia (Kumurur, 2008). Lingkungan menjadi salah satu tahapan dalam menciptakan pola hidup yang sehat.

Sosialisasi terhadap anak-anak terkait dengan cara menjaga pola hidup sehat. Sosialisasi ini merupakan prioritas yang paling peting dalam kegiatan yang dilakukan. Edukasi langsung ditujukan kepada anak-anak. Sosialisasi untuk memaksimalkan upaya penyuluhan terhadap pola hidup sehat kepada anak-anak yang menjadi inti dari program yang kami rencanakan. (Emilia, 2009)

Pembagian masker kepada masyarakat desa sungai pauh. Edukasi tentang pola hidup yang sehat dilakukan kegiatan pembagian masker kepada masyarakat gampong Sungai Pauh sebagai upaya menghimbau masyarakat tentang pentingnya mencegah diri dari tertular nya wabah corona dari hal yang paling kecil sekalipun (Anhusadar \& Islamiyah, 2020).

Secara umum, alur pelaksanaan kegiatan pengabdian masyarakat ini dituangkan dalam bagan berikut: 


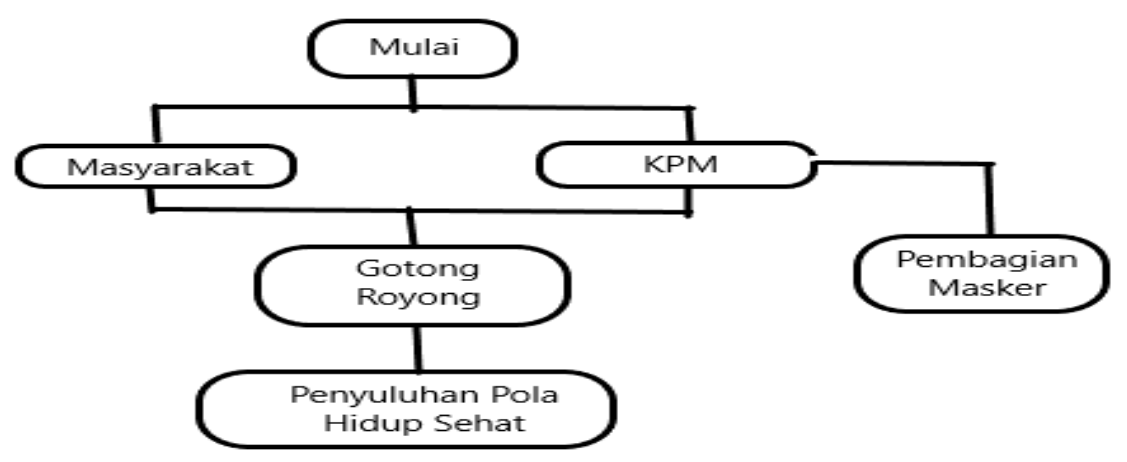

Bagan 1. Kerangka Pemecahan Masalah

\section{HASIL DAN PEMBAHASAN}

Secara umum Kegiatan Pengabdian Masyarakat (KPM) berjalan dengan sangat lancar. Selain mendapat dukungan dari geuchik dan kepengurusan desa. Masyarakat turut aktif membantu dalam proses pelaksanaan kegiatan. Penyuluhan sudah dilakukan sebanyak dua kali, sedangkan aksi lapangan telah dilakukan sebanyak tiga kali, aksi ini dilakukan dengan cara mendirikan apotek hidup, pembagian masker dan juga gotong royong.

Kuliah pengabdian masyarakat telah sukses menerapkan tentang pola hidup yang sehat mencapai tujuannya, yakni dengan mejalankan penyuluhan terkait pola hidup sehat kepada anak. Hasil pengabdian menunjukkan bertambahnya pemahaman anak-anak terhadap pentingnya menjaga pola hidup sehat, serta bertambahnya kesadaran terhadap masing-masing anak untuk menjaga kesehatan pada masa pandemi. Hal ini dapat dilihat dari antusias anak-anak dalam mengikuti kegiatan-kegiatan yang dilakukan untuk mengedukasi tentang penyuluhan pola hidup sehat dan kepedulian mereka terhadap kesehatan seperti mulai menggunakan masker dan mulai rajin mencuci tangan.

Hal ini sejalan dengan berbagai penelitian terdahulu yang pernah meneliti beberapa desa untuk memberikan edukasi melalui penyuluhan kepada masyarakat desa untuk senantiasa menjaga pola hidup yang sehat. Penelitian Wonok dkk (2020) tentang gambaran masyarakat di desa Tumani Kecamatan Maesaan Kabupaten Minahasa Selatan dalam mencegah penularan COVID- 19. Penelitian Melvin tentang bagaimana melakukan pencegahan-pencegahan terhadap tertular nya covid. Emilia (2009) yang meneliti tentang perbandingan gizi, penulis menggunakan penelitian ini sebagai salah satu kajian untuk 
melihat bagaimana dampak gizi terhadap ketahanan imun tubuh anak. Penerapan kebiasaan cuci tangan sejak dini untuk menghimbau tata cara perilaku hidup sehat. (Hermawan et al., 2019). Pengabdian masyarakat yang sudah dilakukan tentang bagaimana menjaga dan menghimbau masyarakat untuk melakukan pola hidup sehat, walaupun masih ada sebahagian masyarakat yang kurang peduli tentang pola hidup sehat. Masih ada beberapa hal yang harus di perhatikan dalam mejalankan pola hidup sehat ini: Rendahnya pemahaman anak terkait pentingnya kebersihan bagi diri sendiri maupun lingkungan sekitar dan Kurangnya pengetahuan anak- anak terkait bahaya covid-19 yang sedang mewabah di Indonesia.

Demikianlah hasil evaluasi kami secara menyeluruh, semoga dapat menjadi pertimbangan penting bagi kegiatan pengabdian lanjutan.

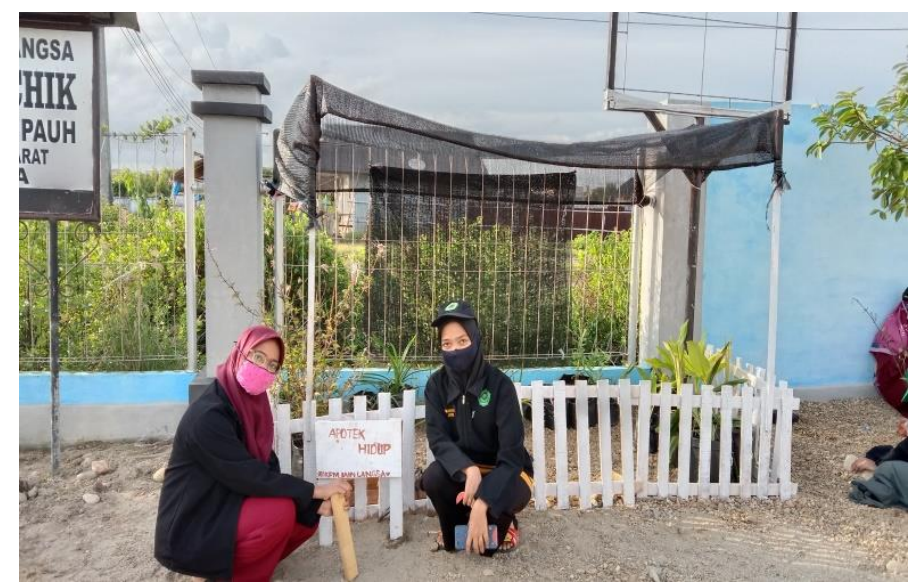

Gambar 1: kegiatan pembuatan apotek hidup

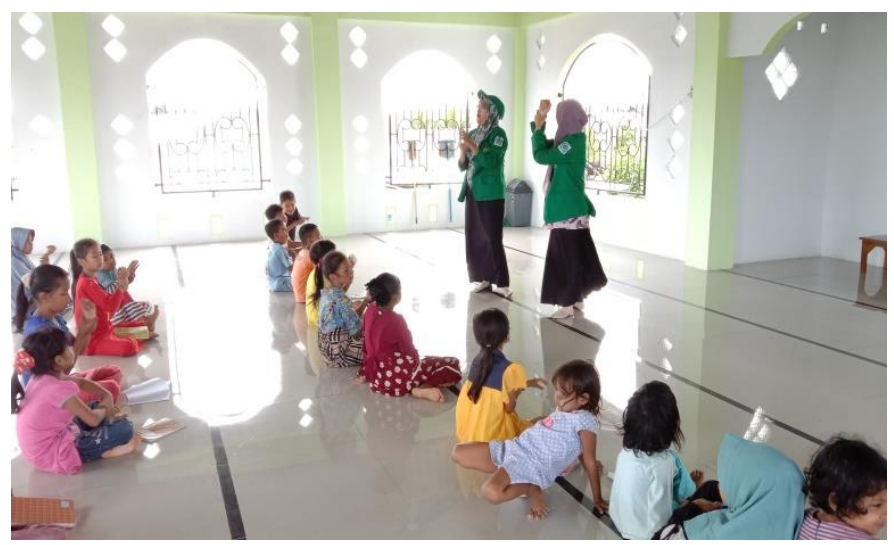

Gambar 2: penyuluhan tentang pola hidup sehat 


\section{KESIMPULAN}

Kegiatan menjaga kesehatan terutama pada masa pandemi dengan menerapkan pola hidup yang sehat, serta menjaga kebersihan lingkungan sekitar. Kesadaran masyarakat tentang pola hidup sehat masih tergolong rendah. Penyuluhan tentang pola hidup sehat perlu dilakukan untuk meningkatkan kesadaran masyarakat untuk menjaga pola hidup sehat.

\section{UCAPAN TERIMAKASIH}

Keberhasilan dalam kegiatan "Upaya Mengedukasi Di Gampong Sungai Pauh Induk Dalam Meningkatkan Pemahaman Terhadap Pola Hidup Sehat" yang dikemas dalam bentuk pengabdian tidak akan berhasil apabila tidak didukung oleh berbagai pihak. Untuk itu, kami sebagai tim pelaksana kegiatan memberikan ucapan terima kasih kami kepada: Lembaga penelitian dan pengabdian masyarakat atau (LP2M) Institut Agama Negeri Islam Langsa yang telah memberikan bantuan sehingga kegiatan kuliah pengabdian masyarakat (KPM) dapat terlaksana dengan baik. Kepada dosen pembimbing lapangan (Supervisor) yaitu Bapak Marimbun. M.Pd. yang telah berkerja keras membimbing dan mengarahkan kami dalam pelaksanaan KPM. Kepada orang tua yang selalu memberikan suport dan dukungan baik secara formil maupun materil. Terimakasih kepada teman-teman yang telah membantu dan memberikan dukungan selama berlangsungnya kegiatan.

\section{DAFTAR PUSTAKA}

Achyar, kresna arief dan juni. (2020). Pengaruh Physical Distancing dan Social Distancing Terhadap Kesehatan Dalam Pendekatan Linguistik. In Handbook of Pediatric Retinal OCT and the Eye-Brain Connection (pp. 285-287). https://doi.org/10.1016/B978-0-32360984-5.00062-7

Anhusadar, L., \& Islamiyah, I. (2020). Penerapan Perilaku Hidup Bersih dan Sehat Anak Usia Dini di Tengah Pandemi Covid 19. Jurnal Obsesi: Jurnal Pendidikan Anak Usia Dini, 5(1). https://doi.org/10.31004/obsesi.v5i1.555

Emilia, E. (2009). Pengetahuan, Sikap dan Praktek Gizi pada Remaja dan Implikasinya pada Sosialisasi Perilaku Hidup Sehat. Media Pendidikan, Gizi, Dan Kuliner, 1(1).

Hermawan, S., Sutandi, P., Setiawan, A., William, S., \& Sumarno, K. (2019). Penerapan Kebiasaan Cuci Tangan Sejak Dini Untuk Perubahan Perilaku Hidup Sehat. Jurnal Leverage, Engagement, Empowerment of Community, 1(2).

Kesehatan, K. (2019). Novel Corona Virus. A $\gamma \alpha \eta, 8(5), 55$.

Kumurur, V. A. (2008). Pengetahuan, Sikap dan Kepedulian Mahasiswa Pascasarjana Ilmu 
Lingkungan Terhadap Lingkungan Hidup Kota Jakarta. 8(2), 1-24.

Marni Br Karo. (2020). Perilaku Hidup Bersih dan Sehat (PHBS). Jurnal Keperawatan Komunitas, 01(01).

Maulida, H., W, R. Y. P., \& Nugrahenti, M. C. (2020). Komunikasi Kesehatan Perilaku Hidup Sehat \#JSR Di Media Sosial. Jurnal Teras Kesehatan, 3(1). https://doi.org/10.38215/jutek.v3i1.44

Messakh, S. T., Purnawati, S. S., \& Panuntun, B. (2019). Gambaran Perilaku Hidup Bersih dan Sehat Siswa Sekolah Dasar Negri di Kecamatan Banyak. Jurnal Ilmu Keperawatan Dan Kebidanan, 10(1). https://doi.org/10.26751/jikk.v10i1.477

Safitri, H. I., \& Harun, H. (2020). Membiasakan Pola Hidup Sehat dan Bersih pada Anak Usia Dini Selama Pandemi Covid-19. Jurnal Obsesi : Jurnal Pendidikan Anak Usia Dini, 5(1), 385. https://doi.org/10.31004/obsesi.v5i1.542

Syarif, P., Suryotomo, B., \& Soeprapto, H. (2011). Diskripsi dan Manfaat Tanaman Obat di Pedesaan Sebagai Upaya Pemberdayaan Apotik Hidup (Studi Kasus di Kecamatan Wonokerto). Pena Jurnal Ilmu, 21(1), 20.

Utomo, F. M. H. J. I. S. D. P. (2020). Meningkatkan Kesadaran Masyarakat Dalam Menjaga Kebersihan Lingkungan Sebagai Upaya Pencegahan Penyebaran Covid. 9(7), 147-156.

Wonok, M. J., Wowor, R., \& Tucunan, A. A. (2020). Gambaran perilaku masyarakat tentang pencegahan covid-19 di desa tumani kecamatan maesaan kabupaten minahasa selatan. Kesmas, 9(7).

Yunus, N. R., \& Rezki, A. (2020). Kebijakan Pemberlakuan Lock Down Sebagai Antisipasi Penyebaran Corona Virus Covid-19. SALAM: Jurnal Sosial Dan Budaya Syar-I, 7(3). https://doi.org/10.15408/sjsbs.v7i3.15083 